\title{
Investigation of isotopic signals in the unsaturated zone with the use of direct push technology and azaeotropic distillation
}

\section{Indagine sui segnali isotopici nella zona insatura mediante l'uso di tecnologia direct push e distillazione azerotropica}

Kallioras A, Piepenbrink M., Khan A., Reshid M., Rausch R., Dietrich P., Schuth C.

Riassunto: L'articolo contribuisce allo studio della zona insatura, mediante applicazione di tecniche di campo e di laboratorio. I risultati mostrano che i metodi di tipo direct push, che sono considerati ideali per il campionamento multilivello indisturbato nella zona insatura, è efficace anche per la successiva estrazione di acqua interstiziale per le successive analisi istopiche. Questo obiettivo finale può essere conseguito grazie all'applicazione di distillazione azeotropica, che ha minore effetti di frazionamento isotopico sui campioni di acque sotterranee.

Parole chiave: Zona insatura, estrazione acqua interstiziale, campionamento multilivello indisturbato in zona insatura, tecnologia direct push

Keywords: Unsaturated zone, porewater extraction, multilevel undisturbed soil sampling, direct push technology

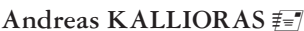

National Technical University of Athens, Greece

Helmholtz Centre for Environmental Research - UFZ, Leipzig, Germany

kallioras@metal.ntua.gr

andreas.kallioras@ufz.de

\section{PIEPENBRINK}

A. KHAN

M. RESHID

C. SCHUTH

Technical University of Darmstadt, Germany

R. RAUSCH

GIZ - International Services, Riyadh Office, Kingdom of Saudi Arabia.

P. DIETRICH

Helmholtz Centre for Environmental Research - UFZ, Leipzig, Germany.

Ricevuto: 24 luglio 2012 / Accettato: 14 settembre 2012

Pubblicato online: 30 settembre 2012

(C) Associazione Acque Sotterranee 2012
Abstract: This paper contributes to the investigation of the unsaturated zone, through the application of combined field and lab techniques. The results show that direct push methods, which are considered ideal for multilevel sampling of undisturbed soil in the unsaturated zone, proved to be effective also for the consequent extraction of the pore water for further isotopic determination. This ultimate goal can be achieved thank to the application of azaetropic distillation, which has the least isotopic fractionation effects on groundwater samples.

\section{Introduction}

Unsaturated zone may be considered as an intermediate hydrologic zone, which separates the ground surface from the saturated zone, playing a key role for the investigation of not only groundwater recharge but for the entire hydrologic system, as it can provide an archive of past and present hydrologic events. Unsaturated zone investigations can be conducted either quantitatively or qualitatively, by studying both the quantity as well as the quality of the infiltrating water that eventually percolates and recharges the underlying aquifer presently and in the past. Thus unsaturated zone may be seen as a precious "bank of field hydrologic data" which in turn can be used to retrieve valuable information regarding the water flux through the unsaturated column. Edmunds and Tyler (2002), in their review with respect to unsaturated zones as archives of past climates, point out that several problems remain in relating observed profiles in some areas to the knowledge of soil-moisture movement and that the field is still relatively new and there is significant promise. Geophysical techniques (e.g. ground penetrating radar surveys) are proved to serve effectively the unsaturated zone investigations in order to quantify the soil moisture profile of the unsaturated column down to significant depths (some tenths of meters). Also the development of different multilevel soil sampling techniques has lead to the successful retrieval of undisturbed soil samples through the unsaturated column providing detailed analysis of the hydrogeological properties of the soil matrix as well as of the isotopic composition of the pore water (after appropriate water extraction technique is applied). 
The ${ }^{18} \mathrm{O}$ and ${ }^{2} \mathrm{H}$ values of pore water extracted from saturated and unsaturated geologic, soil, and lacustrine cores have been used for decades as natural hydrologic tracers to study paleoclimate, soil vapor fluxes, and in determining the origin and movement of pore water in water resource evaluation, groundwater contamination, and nuclear waste storage studies (Wassenaar et al., 2008). Up to present the mostly used techniques for extracting porewater from soil matrix retrieved from the saturated or unsaturated zone include the application of: centrifugation (Edmunds and Bath, 1976; Zornberg and McCartney, 2010; Kinniburgh and Miles, 1983; Kelln et al., 2007), press and/or squeezing (Boettcher et al., 1997), vacuum distillation (Allison and Hughes, 1983; Allison and Hughes, 1976; Araguas-Araguas et al., 1995; Fontes et al., 1986) , cryogenic microdistillation (West et al., 2006; Heilweil et al., 2006), leaching (Figueroa-Johnson et al., 2007; Ingraham and Shadel, 1992; Walker et al., 1994), equilibration and azeotropic distillation (Landon et al., 1999; Komor and Emerson, 1994; Sacchi et al., 2001; Scromgeour, 1995).

In conclusion, one could argue that the main errors associated with distillation techniques (vacuum and azeotropic) are of quantitative nature, due to incomplete extraction of the soil water. However, azeotropic distillation is proved to be the most effective pore water extraction technique, especially for soil samples with very low water content. Scromgeour (1995) states that, although the accuracy is somewhat reduced in samples containing high levels of organic matter or very low water content, azeotropic distillation remains the "gold standard" against which other methods must be tested.

The development of effective pore water extraction techniques, gave rise to the extensive investigation of the isotopic composition of the soil water within the unsaturated zone. Edmunds (2009) points out that the application of environmental isotopes in hydrology dates back to 1935 , when oxygen isotope ratios were first measured on Lake Michigan water by Dole (1935). With special reference to the stable isotopes, their investigation on the role of the unsaturated zone was thoroughly presented by Dincer et al. (1974) through studies of the infiltration and recharge through the sand dunes in arid zones with special reference to the stable isotopes and thermonuclear tritium. Later on, Allison (1982) investigated the effect of evaporation on stable isotope composition in the unsaturated zone, in order to analyse the water movement in dry soils. Additionally Barnes and Allison (1983), Allison et al. (1983), Allison and Hughes (1983) and Barnes and Allison (1988) used stable isotopes of deuterium and oxygen for the investigation of water fluxes in dry soils which are subjected to high evaporation effects. Scanlon (2000) used data from environmental tracers, including meteoric $\mathrm{Cl},{ }^{36} \mathrm{Cl},{ }^{3} \mathrm{H},{ }^{2} \mathrm{H}$, and ${ }^{18} \mathrm{O}$ in porous media in order to evaluate uncertainties in water flux and age. In their studies of groundwater recharge in the Kalahri, de Vries et al. (2000) discussed moisture and vapor transport from depths below the root zone within the unsaturated zone. McConville et al. (2001), in their studies for quantification of groundwater recharge in a small temperate catchment, used stable isotopes of oxygen in the unsaturated zone. Stumpp et al. (2007) present an approach which enables the quantification, in integrative form, of the preferential flow and the heterogeneity in water transport through the unsaturated zone under natural atmospheric conditions.

Kelln et al. (2001) collected pore waters from piezometers installed in a thick clay-rich till in order to compare and evaluate four techniques of pore water sampling to obtain ${ }^{2} \mathrm{H}$ and $\delta^{18} \mathrm{O}$ values in these media: mechanical squeezing, centrifugation, azeotropic distillation and a direct soil-water equilibration technique. The results of this study show that the azeotropic distillation produced a discrepancy in ${ }^{2} \mathrm{H}$ and ${ }^{18} \mathrm{O}$ measurements comparable with the other techniques. According to Golvan et al. (1997), a second problem concerns the isotopic differences between mobile water and weakly bound water, and the possibility of partially extracting the latter during distillation. Araguas-Araguas et al. (1995) mention that the depletion in ${ }^{2} \mathrm{H}$ and ${ }^{18} \mathrm{O}$ (by $5-10 \%$ and $0.3-0.5 \%$, respectively), after the application of the water extraction technique, depends strongly on the soil type, and the reproducibility for replicate extractions of soil water from clayey soils is around $\pm 3 \%$ and $0.3 \%$ for ${ }^{2} \mathrm{H}$ and ${ }^{18} \mathrm{O}$, respectively.

As the issue of porewater extraction from undisturbed soils samples is of paramount importance for unsaturated zone studies, new techniques are under development which appear promising for more effective porewater extractions in the future. Wassennar et al. (2008) developed a new $\mathrm{H}_{2} \mathrm{O}$ (liquid)$\mathrm{H}_{2} \mathrm{O}$ (vapor) pore water equilibration and laser spectroscopy method (which is also mentioned on previous investigation made by Scrimgeour, 1995; Hsieh et al., 1998; McConville et al., 1999; Koehler et al., 2000; Gazis and Feng, 2004) provides a fast way to obtain accurate high resolution $(30 \mathrm{~cm})^{2} \mathrm{H}$ and ${ }^{18} \mathrm{O}$ profiles from single core samples from saturated and unsaturated geologic media. The same authors (Wassenaar et al., 2008) mention that the precision and accuracy of the $\mathrm{H}_{2} \mathrm{O}$ (liquid) $-\mathrm{H}_{2} \mathrm{O}$ (vapor) equilibration method was comparable to or better than conventional IRMS-based methods, and it can be conducted on geologic cores that contain volumetric water contents as low as 5\%. Koehler et al. (2009) retrieved core samples from two near-surface clay-rich Late Pleistocene aquitard systems near Lanigan and Colonsay, Saskatchewan, Canada, as part of a hydrogeologic investigation. They concluded that direct equilibration of porewater in core samples of clay-rich geologic media with $\mathrm{H}_{2}$ and $\mathrm{CO}_{2}$ was used to accurately determine their ${ }^{2} \mathrm{H}$ and ${ }^{18} \mathrm{O}$ values, and the precision (0.3 and $1 \%$, respectively) and accuracy of the direct equilibration method was comparable to most currently employed methods and considerably better than some.

This paper presents the results of the synthesis and combination of field as well as laboratory techniques in order to realize the research approaches as shown in Figure 1. The unsaturated zone experiments are carried out an experimental field site with a tailored scientific infrastructure (AugustEuler Airport of TU Darmstadt, Germany), where the unsaturated zone has a thickness of approximately $15 \mathrm{~m}$ and 
UNSATURATED ZONE RESEARCH ACTIVITIES
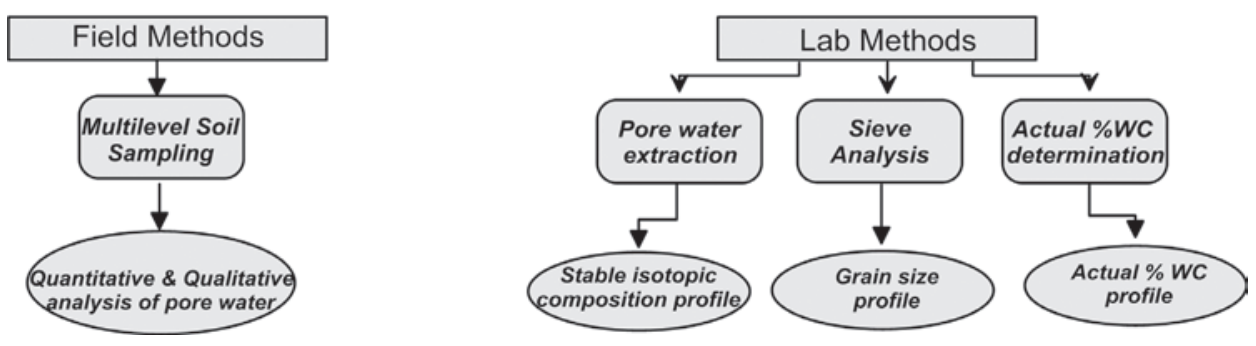

Fig. 1 - Schematic conceptualization of research approach and activities.

Fig. 1 - Schema concettuale dell'approccio di ricerca e delle attività

consists of unconsolidated fine sands of aeolian origin. The site offers the advantage to test and optimize the techniques under well controlled conditions. Both requirements (retrieval of undisturbed soil samples and installation of monitoring equipment) can be satisfied by applying a direct push technology that was developed to take undisturbed soil cores from unconsolidated formations. The technique uses vibration to penetrate the subsurface with a hollow casing that contains an inner sampling liner. When the required depth is reached, the casing with the sampling liner is withdrawn and the liner can be capped for further analysis. No drilling fluids are necessary that would alter water content and water chemistry. In a second step, the open borehole can be used for the installation of monitoring equipment again using direct push methods.

Shallow $(<15 \mathrm{~m})$ monitoring wells were rapidly and efficiently installed using Geoprobe machinery (direct push drilling techniques). A casing is vibrated into the ground using a variable frequency vibrator which is clamped to the outside of the sample tube. The undisturbed sample rises up inside the sample tube and is retained by a corecatcher at the base of the sample tube. When the required sample length has been acquired, or refusal met, the sample tube/liner is withdrawn from the formation, the sample capped and identified and the tube or replacement returned to the borehole.

The applications and disadvantages of this method can be summarised as follows:

$>$ Applications of vibro-coring

- Undisturbed formation sampling in unconsolidated formations to $30 \mathrm{~m}$ depths

- Very rapid

- Minimal contamination of samples (as no drilling fluids are required when sampling)

- Rapid installation of shallow monitoring systems.

$>$ Limitations of vibro-coring

- Can only be used to shallow depths (i.e. down to 2530m)

- Drilling can be stopped by cobbles, pebbles etc.

- Not feasible to drill through consolidated formations.
As direct push technology is ideal for obtaining multilevel undisturbed soil samples from unconsolidated formations, the retrieved undisturbed soil samples are used for further analyses (among others, sieve analysis, porewater extraction, oven drying, stable isotopic composition) in order to investigate the soil matrix properties and its relation with the water content

\section{Moisture content and grain size analysis}

The application of the direct push vibro-coring technology was selected as an essential part of this research in order to collect undisturbed soil cores from unconsolidated sediments. Undisturbed soil cores were taken from three adjacent boreholes (GP1, GP2 and GP3), from surface down to a depth of approximately $10 \mathrm{~m}$ (Figure 2). The horizontal distance between each drilling location is app. $0.5-2.0 \mathrm{~m}$, within an area of app. $10 \mathrm{~m}^{2}$.

The core liners (35 $\mathrm{mm}$ outer thin walled HDPE material) have an integral core catcher at the end in order to maximize sample recovery and at the same time minimize any entrance losses of sample material. Each soil core liner was partitioned into $30 \mathrm{~cm}$ sections sealed with tailored liner caps and isolated using an aluminum tape in order to eliminate any porewater losses due to evaporation and the soil samples were refrigerated immediately after the field the sampling campaign. Then each liner section was cut longitudinally, and one part of the undisturbed soil sample was used for porewater extraction after azeotropic distillation while the other part was used for thermogravimetric determination of water content as well as sieve analysis.

The partitioning of the liners in sections of $30 \mathrm{~cm}$ aimed to the establishment of high resolution qualitative and quantitative analysis of the porewater within the unsaturated columns (GP1, GP2, GP3). This resulted in the median grain size profile through sieving which is shown in figure 3 , where it can be observed that fine sand particles are present throughout the entire unsaturated column, with smaller particle size being accumulated between a depth of $-5 \mathrm{~m}$ and $-6 \mathrm{~m}$ from the 


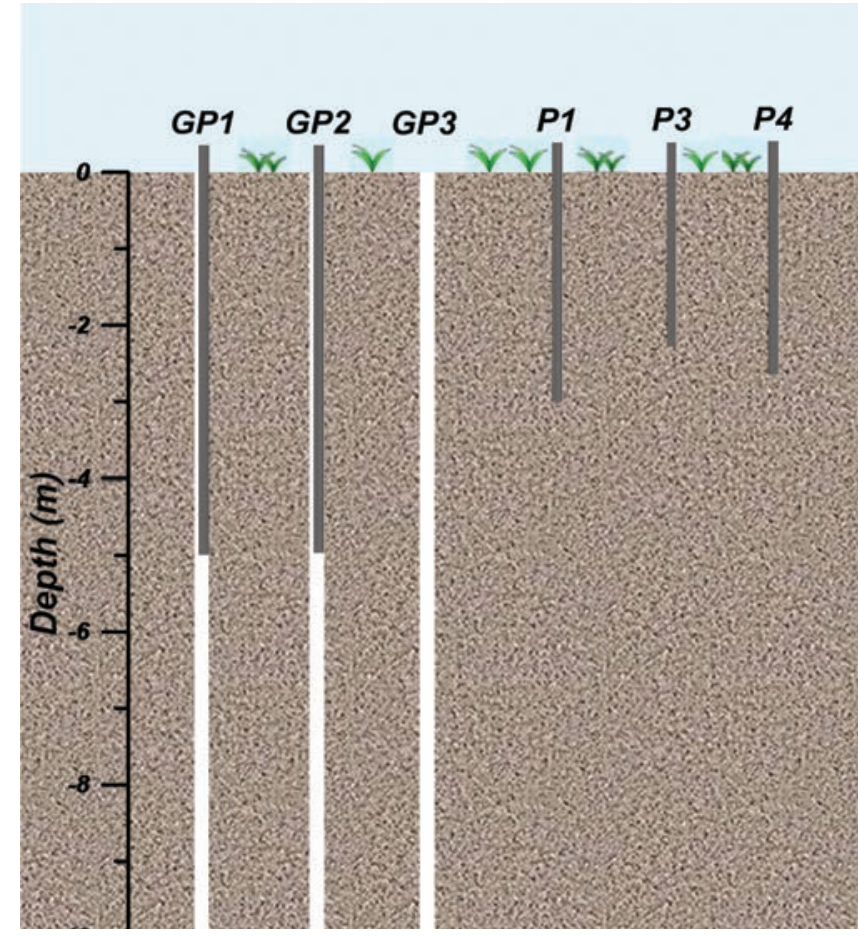

Fig. 2 - Boring with direct push methods for undisturbed soil sampling (white columns) and installation of moisture content monitoring equipment (striped columns).

Fig. 2 - Perforazione con il metodo direct push per campionamento indisturbato del suolo (colonne bianche) e installazione equipaggiamento di misura dell'umidità del suolo (colonne a strisce).

ground surface. The above fact also obstructed the porewater moisture sensors to penetrate deeper down, after the depth of $5 \mathrm{~m}$ below the ground, due to higher friction between the sensor side walls and the surrounding soil material.

Figures 4 to 6 (also considering Figure 3) show the influence of the median grain size pattern on the porewater content down to $10 \mathrm{~m}$ within the unsaturated zone. With respect to Figure 4, it can be realized that larger grain size sands contain the less gravimetric water content observation which is more distinct at the depth of $-4 \mathrm{~m}$ from the ground surface. This observation is even more prominent at depths from $-3 \mathrm{~m}$ to $-4 \mathrm{~m}$ and from $-2.5 \mathrm{~m}$ to $-3.5 \mathrm{~m}$ at boreholes GP2 and GP3 respectively (Figures 5 and 6 ).

The increase in hydraulic conductivity between 2 to $3 \mathrm{~m}$ depth of borehole GP1 and GP3 and 2.5 to $3.5 \mathrm{~m}$ depth for borehole GP2 well corresponds to the decrease in water content at the respective depth. Naturally areas of higher hydraulic conductivity indicate quick release of water from respective depth -due to gravity- and consequently have lower water holding capacity (eventually lower water content) and vice versa. However, overall distribution of hydraulic conductivity shows a decreasing trend vertically downward as depth increases. These findings of decreasing trend of hydraulic conductivity help to interpret the results from measured waveform regarding heterogeneous rate of percolation of the containing pore water.

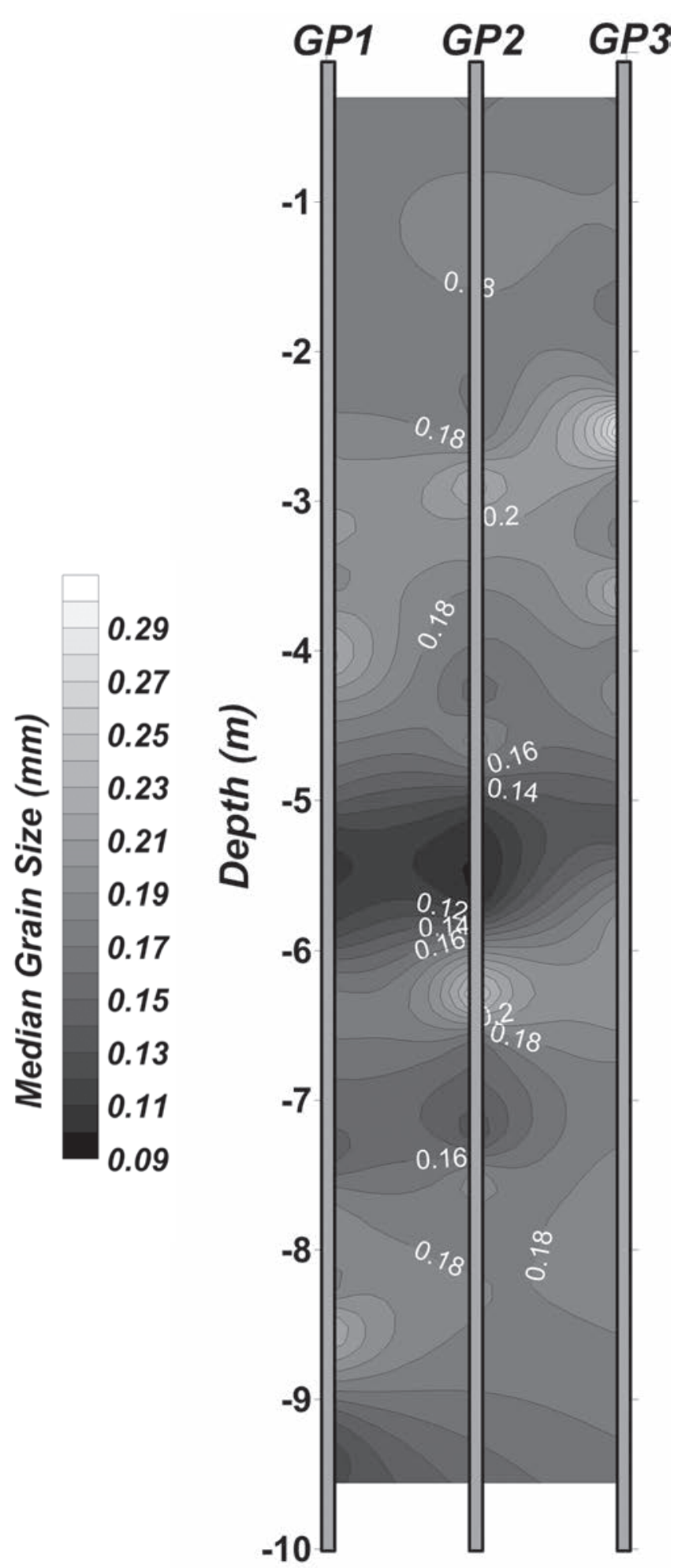

Fig. 3 - Distribution of median grain size ( $\mathrm{mm}$ ) across axis GP1-GP2-GP3 (borizontal distance between each borebole $50 \mathrm{~cm}$ ).

Fig. 3- Distribuzione della granulometria media ( $\mathrm{mm})$ lungo il profilo GP1GP2-GP3 (distanza orizzontale di $50 \mathrm{~cm}$ tra ogni perforo). 


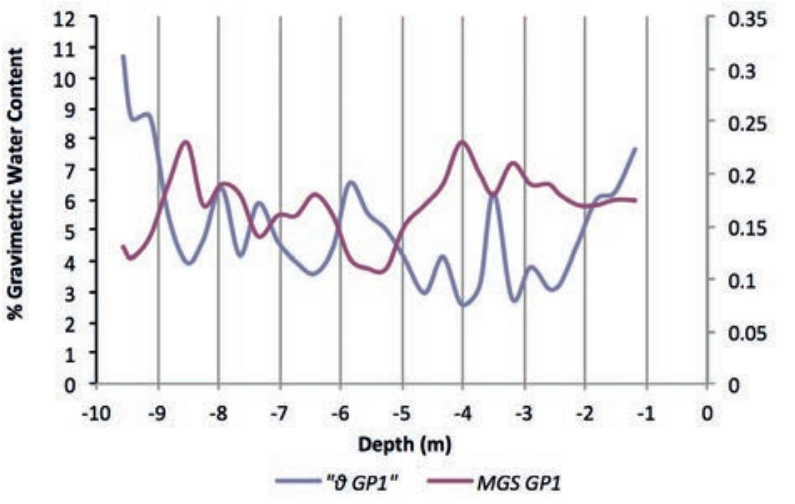

Fig. 4 - Variation of median grain size and gravimetric water content with depth at borebole GP1.

Fig. 4- Variazione della granulometria media $(\mathrm{mm})$ e del contenuto idrico in peso con la profondità nel perforo GP1.

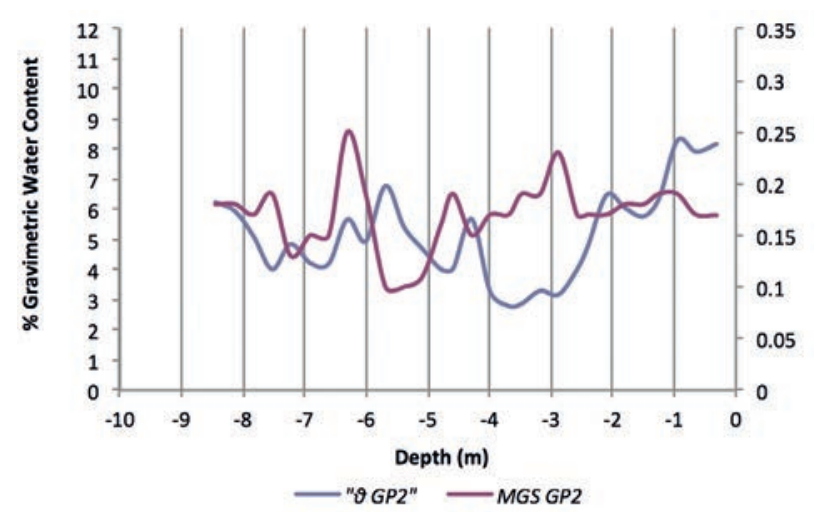

Fig. 5 - Variation of median grain size and gravimetric water content with depth at borehole GP2.

Fig. 5- Variazione della granulometria media $(\mathrm{mm})$ e del contenuto idrico in peso con la profondità nel perforo GP2.

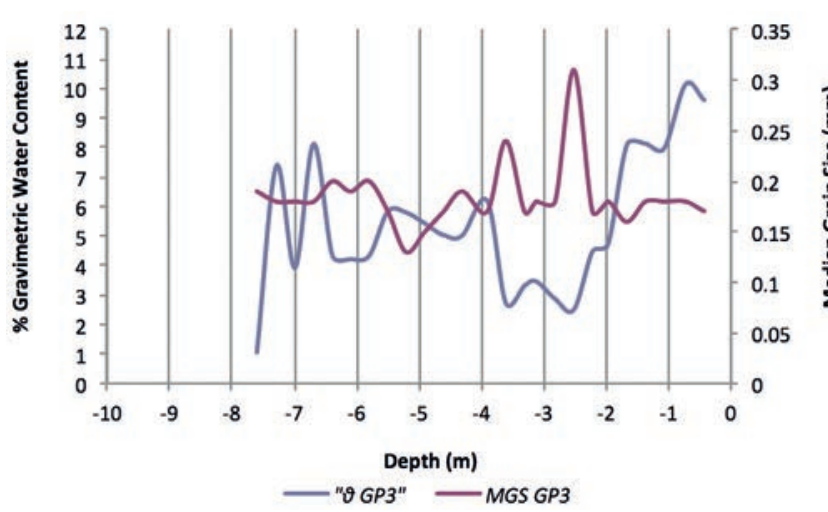

Fig. 6 - Variation of median grain size with gravimetric water content with depth at borebole GP3.

Fig. 6 - Variazione della granulometria media $(\mathrm{mm})$ e del contenuto idrico in peso con la profondità nel perforo GP3.

\section{Extraction of pore water and isotope data}

The ${ }^{18} \mathrm{O}$ and ${ }^{2} \mathrm{H}$ values of porewater extracted from geologic media have been used to determine the age and origin of porewaters, and in some cases, depth trends of ${ }^{18} \mathrm{O}$ and/or ${ }^{2} \mathrm{H}$ values of porewaters have yielded long-term trends of past climatic changes (Koehler et al., 2000). To obtain detailed ${ }^{18} \mathrm{O}$ and ${ }^{2} \mathrm{H}$ profiles from geologic media, stable isotope measurements are most commonly made on porewater that has been obtained using various extraction techniques. These extraction techniques include centrifugation, mechanical squeezing, vacuum heating, cryogenic microdistillation, $\mathrm{CO}_{2}$ equillibration and azeotropic distillation with an immiscible organic solvent such as toluene. Each of these techniques has limitations and the potential for causing isotopic fractionation as part of a multistep extraction process.

Revesz and Woods (1990) developed a method to extract soil water for determination of ${ }^{2} \mathrm{H}$ and ${ }^{18} \mathrm{O}$ content. The principle of this method is based on the observation that water and toluene form an azeotropic mixture at $84.1^{\circ} \mathrm{C}$, but are completely immiscible at ambient temperature. In a specially designed distillation apparatus (Revesz and Woods, 1990), the soil water is distilled at $84.1^{\circ} \mathrm{C}$ with toluene and is separated quantitavely in the collecting funnel at ambient temperature. Tracers of toluene are removed and the sample can be analysed by mass spectrometry.

The undisturbed soil samples which were obtained after the application of direct push drilling techniques, were used for both azeotropic distillation as well as drying oven in order to extract the containing pore water as well as to determine with high accuracy the actual gravimetric water content of the soil at different depths (Figure 7a, b \& c).

Figure 8 shows the gravimetric water content of the undisturbed soil samples after applying azeotropic distillation and drying oven (at $105^{\circ} \mathrm{C}$ for $24 \mathrm{hrs}$ ). From the same figure one can easily observe the different water fronts (downward movement of water -infiltration- through the unsaturated zone column) as well as the similarity of the water content fields measured from azeotropic distillation and drying oven.

Porewater extracted from the undisturbed soil samples were used for the determination of different isotopic signals such as ${ }^{18} \mathrm{O},{ }^{2} \mathrm{H}$ which in turn may be used to investigate groundwater transit times as well as preferential flow paths through the unsaturated zone.

Figures $9 \mathrm{a}$ to $10 \mathrm{~b}$ show a distinct isotopic enrichment which is more pronounced within the upper part of the soil profile fact which is attributed soil moisture evaporation (evaporation losses phenomena). The above observation shows that it is mainly the humidity that really influences and controls the degree of isotope enrichment, while Hoefs (2009) additionally points out that only under very arid conditions, and only in small water bodies, really large enrichments in ${ }^{2} \mathrm{H}$ and ${ }^{18} \mathrm{O}$ are observed. 


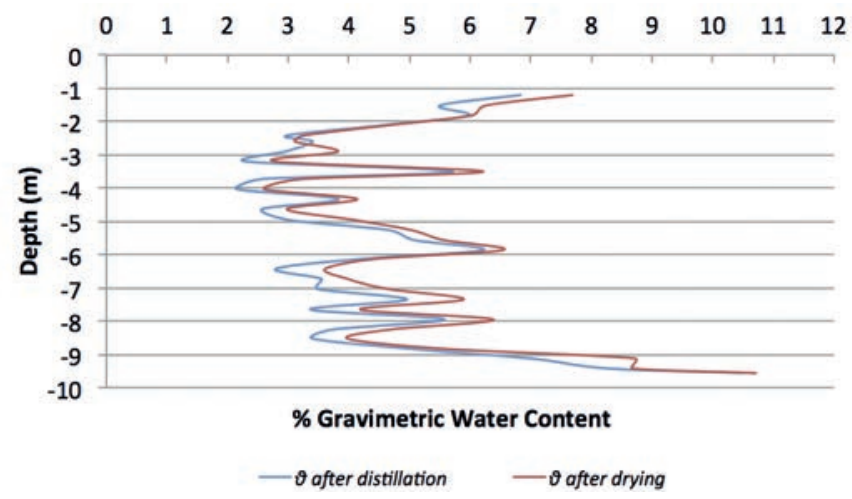

Fig. 7a-Gravimetric water content (\%) at borehole GP1 obtained from (a) azeotropic distillation and (b) oven drying, of the undisturbed soil sample.

Fig. 7 a - Contenuto idrico in peso (\%) nel perforo GP1 ottenuto per (a) distillazione azeotropica e (b) in essiccazione in forno in campione di suolo indisturbato.

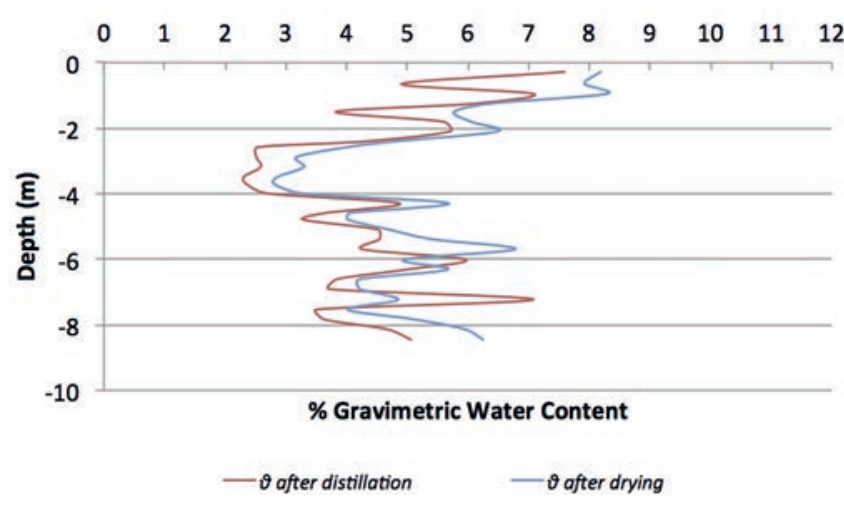

Fig. 76 - Gravimetric water content (\%) at borehole GP2 after (a) azeotropic distillation and $(b)$ oven drying, of the undisturbed soil sample.

Fig. 7b - Contenuto idrico in peso (\%) nel perforo GP2 ottenuto per (a) distillazione azeotropica e (b) in essiccazione in forno in campione di suolo indisturbato.

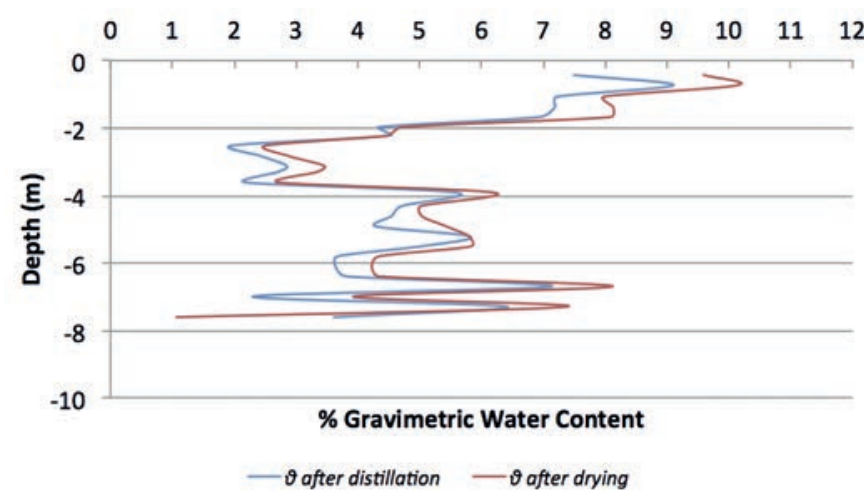

Fig. 7c-Gravimetric water content (\%) at borehole GP3 after (a) azeotropic distillation and (b) oven drying, of the undisturbed soil sample.

Fig. 7c- Contenuto idrico in peso (\%) nel perforo GP3 ottenuto per (a) distillazione azeotropica e (b) in essiccazione in forno in campione di suolo indisturbato.
Azeotropic distillation

Oven drying
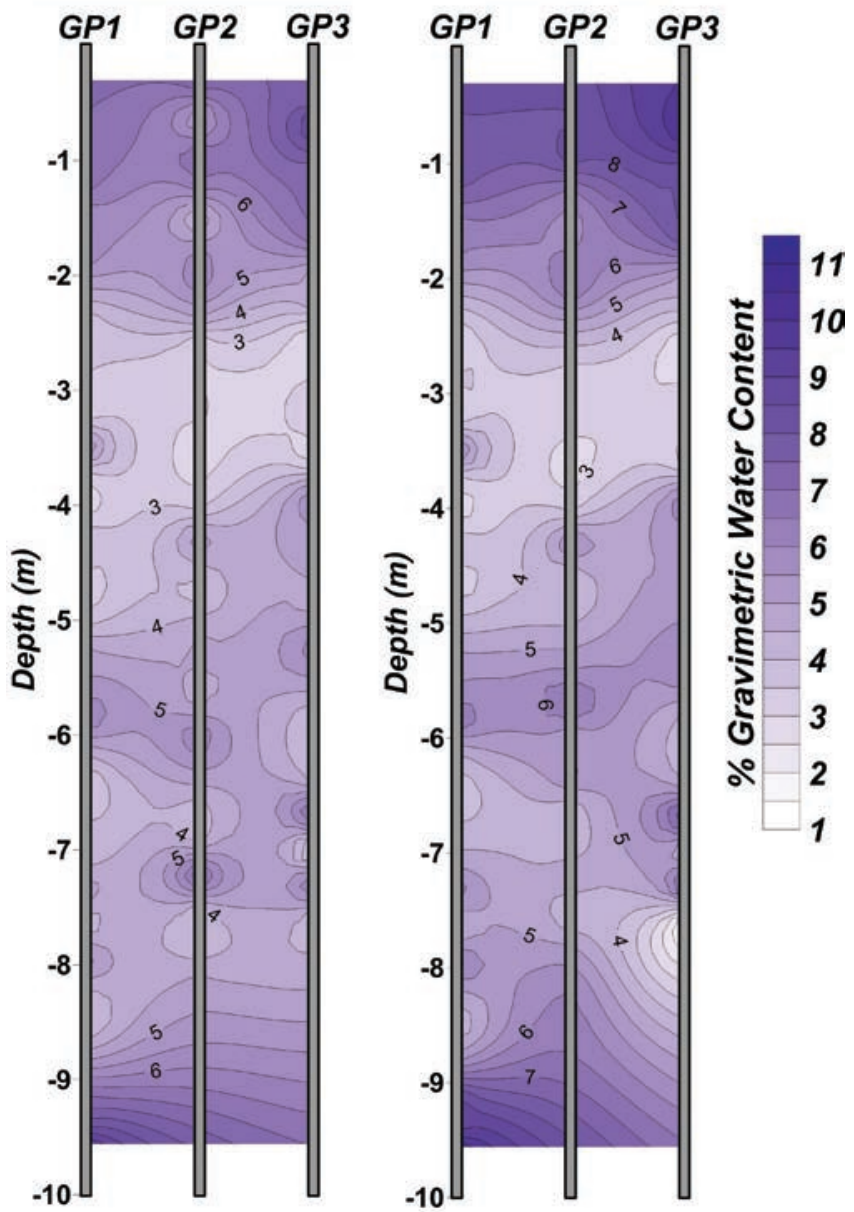

Fig. 8 - \% Gravimetric water content distribution profile along axis GP1-GP2-GP3 (distance between points $0.5 \mathrm{~m}$ )

Fig. 8 - Distribuzione \% del contenuto idrico in peso lungo il profilo GP1GP2-GP3 (distanza orizzontale di $50 \mathrm{~cm}$ tra ogni perforo).

\section{Conclusions}

Unsaturated zone processes play a key role in groundwater recharge as the thickness of the unsaturated zone in arid areas may reach several tens of meters. In principle, the water trapped in the unsaturated zone represents a historic record of infiltration events potentially enabling a quantification of present and past groundwater recharge. Therefore we apply a combination of different experimental techniques that are targeted to retrieve the information contained in the unsaturated zone.

Multilevel undisturbed soil sampling for the extraction of the containing pore water is applied for the dating of the groundwater through the determination of its isotopic composition. The determination of different isotopic signals such as ${ }^{18} \mathrm{O},{ }^{2} \mathrm{H},{ }^{3} \mathrm{H}$, and ${ }^{36} \mathrm{Cl}$, mainly aim to the investigation of groundwater transit times as well as preferential flow paths through the unsaturated zone.

The results have shown a distinct isotopic enrichment which is more pronounced within the upper part of the soil profile 


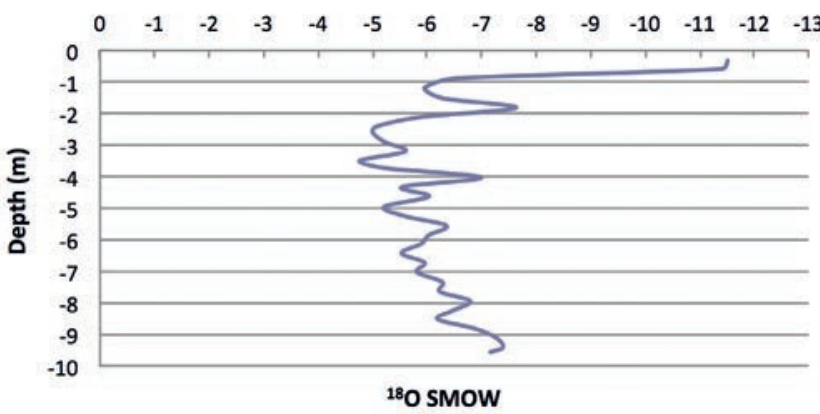

Fig. 9a-Depth profile (borebole GP1) of ${ }^{18} \mathrm{O}$ (\%o relative to SMOW) from porewater samples within the unsaturated zone of the experimental field site (January 2010).

Fig. 9a - Profilo in profondità (perforo GP1) di ${ }^{18} \mathrm{O}$ (\%o relativo a SMOW) per campione di acqua interstiziale nella zona insatura del sito del campo sperimentale (Gennaio 2010).

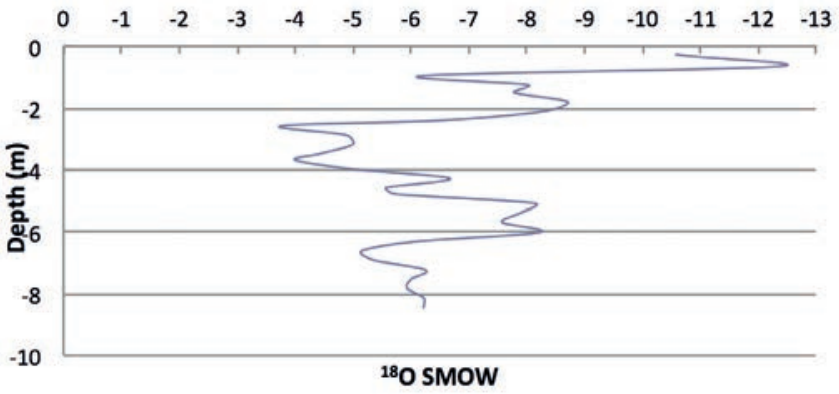

Fig. $10 a$ - Depth profile (borebole GP2) of ${ }^{18} \mathrm{O}$ (\%orelative to SMOW) from porewater samples within the unsaturated zone of the experimental field site (January 2010).

Fig. 10a - Profilo in profondità (perforo GP2) di ${ }^{18} \mathrm{O}$ (\%o relativo a SMOW) per campione di acqua interstiziale nella zona insatura del sito del campo sperimentale (Gennaio 2010).

fact which is attributed soil moisture evaporation (evaporation losses phenomena). Larger grain size sands contain the less gravimetric water content observation which is more distinct at a certain depth below the ground surface.

As expected, the increase in hydraulic conductivity at certain depths corresponded to a decrease in water content at the respective depth, as higher hydraulic conductivity indicate quick release of water from respective depth -due to gravity.

The unsaturated zone experiments were carried out at a selected field site of the Technical University of Darmstadt, where the local conditions (unsaturated zone composed of aeolian sands and a thickness of approximately $20 \mathrm{~m}$ ) were found ideal for unsaturated zone experiments.

\footnotetext{
Ackowledgements: The authors would like to acknowledge the cooperation between Technical University of Darmstadt (Germany), Helmholtz-Centre for Environmental Research-UFZ (Leipzig, Germany), GIZ-IS (Riyadh Offices, Saudi Arabia) and the Ministry of Water and Electricity-MoWE, Kingdom of Saudi Arabia; within the framework of the BMBF funded research program IWAS (http:// www.iwas-sachsen.ufz.de/).
}

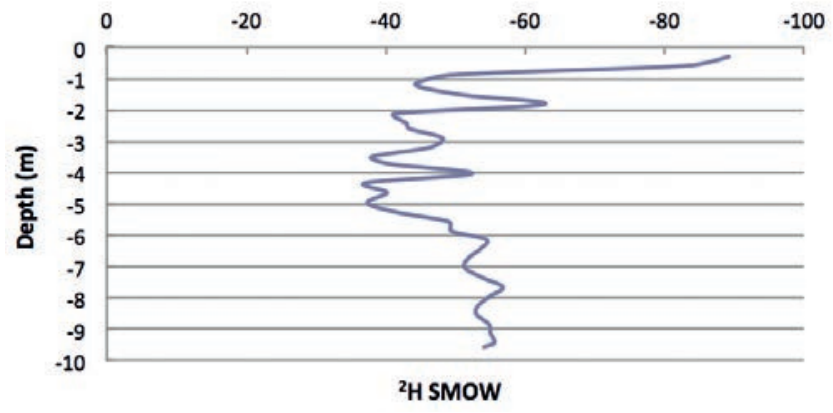

Fig. 9b-Depth profile (borebole GP1) of ${ }^{2} \mathrm{H}$ (\%o relative to SMOW) from porewater samples within the unsaturated zone of the experimental field site (January 2010).

Fig. 9b - Profilo in profondità (perforo GP1) di ${ }^{2} \mathrm{H}$ (\%o relativo a SMOW) per campione di acqua interstiziale nella zona insatura del sito del campo sperimentale (Gennaio 2010)

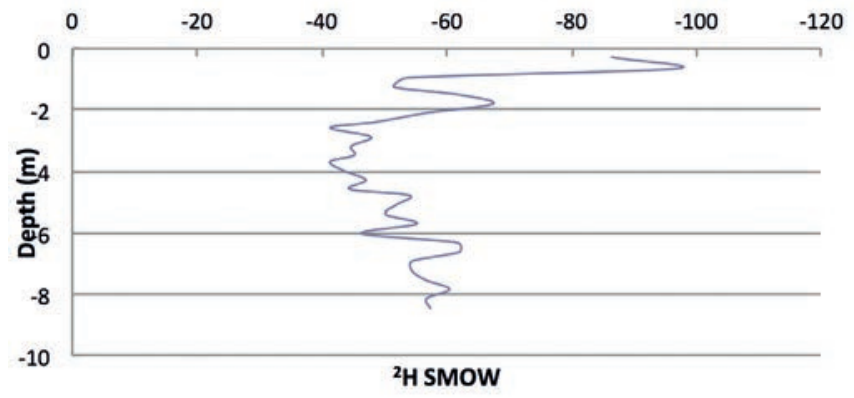

Fig. $10 b$ - Depth profile (borehole GP2) of ${ }^{2} \mathrm{H}$ (\%o relative to SMOW) from porewater samples within the unsaturated zone of the experimental field site (January 2010). Fig. 10b - Profilo in profondità (perforo GP2) di ${ }^{2} \mathrm{H}$ (\%o relativo a SMOW) per campione di acqua interstiziale nella zona insatura del sito del campo sperimentale (Gennaio 2010).

\section{References}

Allison B. B. and Hughes M. W. (1983). The use of natural tracers as indicators of soil-water movement in a temperate semi-arid region, Journal of Hydrology, 60: 157-173.

Allison G. B. (1982). The relationship between ${ }^{18} \mathrm{O}$ and deuterium in water sand columns undergoing evaporation. Journal of Hydrology, 55:163-169.

Allison G. B., Barnes C. J., Hughes M. W. (1983). The distribution of deuterium and ${ }^{18} \mathrm{O}$ in dry soils: 2. Experimental, Journal of Hydrology, 64:377-397.

Araguas-Araguas L., Rozanski K, Gonfiantini R, Louvat D. (1995). Isotope effects accompanying vacuum extraction of soil water for stable isotope analyses. Journal of Hydrology 168:159-171.

Barnes C. J. and Allison G. B. (1983). The distribution of deuterium and ${ }^{18} \mathrm{O}$ in dry soils: 1 . Theory, Journal of Hydrology, 60:141-156.

Barnes C. J. and Allison G. B. (1988). Tracing of water movement in the unsaturated zone using stable isotopes of hydrogen and oxygen. Journal of Hydrology, 100:143-176.

Boettcher G., Brumsack H.-J., Heinrichs H. Pohlmann M. (1997). A new high-pressure squeezing technique for pore fluid extraction from terrestrial soils. Water, Air, and Soil Pollution, 94:289-296. 
Coquet Y., Coutadeur C., Labat C., Vachier P., van Genuchten M. Th., Roger-Estrade J., and Simunek J. (2005). Water and Solute Transport in a Cultivated Silt Loam Soil: 1. Field Observations. Vadose Zone Journal, 4:573-586.

de Vries J. J., Selaolo E.T., Beekman H.E. (2000). Groundwater recharge in the Kalahari, with reference to paleo-hydrologic conditions, Journal of Hydrology, 238:110-123.

Dincer T. and Davis G. H. (1984). Application of environmental isotope tracers to modeling hydrology, Journal of Hydrology, 68:95-113.

Dincer T., Al-Mugrin A., Zimmermann U. (1974). Study of the infiltration and recharge through the sand dunes in arid zones with special reference to the stable isotopes and thermonuclear tritium, Journal of Hydrology, 23:79-109.

Dole M., (1935). The relative atomic weight of oxygen in water and air. Bur. Stand. J.

Dregne H. E. (1991). Global status of desertification. Annals of Arid Zone 30: 179-185.

Edmunds W. M. (2009). Geochemistry's vital contribution to solving water resource problems, Applied Geochemistry, 24:1058-1073.

Edmunds W. M. and Bath A. H. (1976). Centrifuge Extraction and Chemical Analysis of Interstitial Waters. Environmental Science and Technology, 10(5):467-472.

Edmunds W. M. and Tyler S.W. (2002). Unsaturated zones as archives of past climates: toward a new proxy for continental regions. Hydrogeology Journal, 10:216-228.

Figueroa-Johnson M. A., Tindall J. A., Friedel M. (2007). A Comparison of ${ }^{18} \mathrm{O} \delta$ Composition of Water Extracted from Suction Lysimeters, Centrifugation and Azeotropic Distillation. Water, Air and Soil Pollution, 184:63-75

Fontes J. Ch., Yousfi M. and Allison G. B. (1986). Estimation of longterm, diffuse groundwater discharge in the Northern Sahara using stable isotope profiles in soil water. Journal of Hydrology, 86:315-327.

Gazis C. and Feng X. (2004). A stable isotope study of soil water: evidence for mixing and preferential flow paths. Geoderma, 119:97- 111.

Heilweil V. M., Solomon D. K. and Gardner P. M. (2006). Borehole Environmental Tracers for Evaluating Net Infiltration and Recharge through Desert Bedrock. Vadose Zone Journal, 5:98-120.

Hendry M. J. and Wassenaar L. I. (2009). Inferring Heterogeneity in Aquitards Using High-Resolution $\delta \mathrm{D}$ and $\delta^{18} \mathrm{O}$ Profiles. Ground Water, 47(5):639-645.

Hoefs J. (2009). Stable Isotope Geochemistry, Springer-Verlag Berlin Heidelberg, 6th Edition, 285p.

Hsieh J. C. C., Savin S. M., Kelly E. F., Chadwick O. A. (1998). Measurement of soil-water $\delta^{18} \mathrm{O}$ values by direct equilibration with $\mathrm{CO}_{2}$. Geoderma, 82:255-268.

Ingraham N. L. and Shadel C. (1992). A comparison of the toluene distillation and vacuum/heat methods for extracting soil water for stable isotopic analysis, Journal of Hydrology, 140:371-387.

Kelln C. J., Wassenaar L. I. and Hendry M. J. (2001). Stable Isotopes $\left(\delta^{18} \mathrm{O}, \delta^{2} \mathrm{H}\right)$ of pore waters in Clay-Rich Aquitards: A comparison and evaluation of measurement techniques. Groundwater Monitoring and Remediation, GWMR Spring 2001, pp. 108-116.

Kelln C., Barbour L. and Qualizza C. (2007). Preferential Flow in a Reclamation Cover: Hydrological and Geochemical Response. ASCE Journal of Geotechnical and Geoenvironmental Engineering, 133(10):1277-1289.

Kinniburgh D. G. and Miles D. L. (1983). Extraction and Chemical Analysis of Interstitial Water from Soils and Rocks. Environmental Science and Technology, 17:362-368.

Koehler G., Wassenaar L. I. and Hendry M. J. (2000). An Automated Technique for Measuring $\delta \mathrm{D}$ and $\delta^{18} \mathrm{O}$ values of porewater by direct $\mathrm{CO}_{2}$ and $\mathrm{H}_{2}$ equilibration. Anal. Chem., 72:5659-5664.
Komor S. C. and Emerson D. G. (1994). Movement of water, solutes, and stable isotopes in the unsaturated zones of two sand plains in the upper Midwest. Water Resources Research, 30:253-267.

Landon M. K., Delina G. N., Komorb S. C. and Regan C. P. (1999). Comparison of the stable-isotopic composition of soil water collected from suction lysimeters, wick samplers, and cores in a sandy unsaturated zone. Journal of Hydrology, 224:45-54.

McConville C., Kalin R. M. and Flood D. (1999). Direct Equilibration of Soil Water for $\mathrm{d}^{18} \mathrm{O}$ Analysis and its Application to Tracer Studies. Rapid Communications in Mass Spectrometry, 13:1339-1345.

McConville C., Kalin R. M., Johnston H., McNeill G. W. (2001). Evaluation of recharge in a small temperate catchment using natural and applied $\delta^{18} \mathrm{O}$ profiles in the unsaturated zone, Ground Water, 39(4):616-623.

Murdoch L. C., Slack W.W., Harrar W., Siegrist R. L. (2000). Embedded sidewall samplers and sensors to monitor the subsurface. Ground Water, 38(5): 657-664.

Revezs, K. \& Woods, P.H. (1990): A method to extract soil water for stable isotope analysis, J. Hydrol., 115:397-406.

Sacchi E., Michelot J.-L., Pitsch H., Lalieux P. and Aranyossy J.-F. (2001). Extraction of water and solutes from argillaceous rocks for geochemical characterisation: Methods, processes, and current understanding. Hydrogeology Journal, 9:17-33.

Scanlon B. R. (2000). Uncertainties in estimating water fluxes and residence times using environmental tracers in an arid unsaturated zone, Water Resources Research, 36(2):395-409.

Scanlon B. R., Keese K. E., Flint A. L. and Flint L. E. (2006). Global synthesis of groundwater recharge in semiaridand arid regions, Hydrol. Process, 20:3335-3370.

Scanlon B.R., Healy R.W., Cook P.G. (2002). Choosing appropriate techniques for quantifying groundwater recharge, Hydrogeology Journal, 10: 18-39.

Scrimgeour C. M. (1995). Measurement of plant and soil water isotope composition by direct equilibration methods. Journal of Hydrology, 172:261-274.

Stumpp C., Maloszewski P., Stichler W., Maciejewski S. (2007). Quantification of the heterogeneity of the unsaturated zone based on environmental deuterium observed in lysimeter experiments, Hydrological Sciences Journal, 52(4): 748-762.

Walker G. R., Woods P. A. and Allison G. B. (1994). Interlaboratory comparison of methods to determine the stable isotope composition of soil water. Chemical Geology, 111:297-306.

Wassenaar L. I., Hendry M. J., Chostner V. L. and Lis G. P. (2008). High Resolution Pore Water $\delta^{2} \mathrm{H}$ and $\delta^{18} \mathrm{O}$ Measurements by $\mathrm{H}_{2} \mathrm{O}$ (liquid)- $\mathrm{H}_{2} \mathrm{O}$ (vapor) Equilibration Laser Spectroscopy. Environ. Sci. Technol., 42:9262-9267.

Weihermüller L., Siemens J., Deurer M., Knoblauch S., Rupp H., Göttlein A., Pütz T. (2007). In Situ Soil Water Extraction: A Review. Journal of Environmental Quality, 36:1735-1748.

West A. G., Patrickson S. J. and Ehleringer J. R. (2006). Water extraction times for plant and soil materials used in stable isotope analysis. Rapid Communications in Mass Spectrometry, 20:1317-1321.

Yann Moreau-Le Golvan and Jean-Luc Michelot (1997). Stable isotope contents of porewater in a claystone formation (Tournemire, France): assessment of the extraction technique and preliminary results. Applied Geochemistry, 12:739-745.

Zornberg J. G. and McCartney J. S. (2010). Centrifuge Permeameter for Unsaturated Soils.I: Theoretical Basis and Experimental Developments. Journal of Geotechnical and Geoenvironmental Engineering (ASCE), 136(8):1051-1063. 